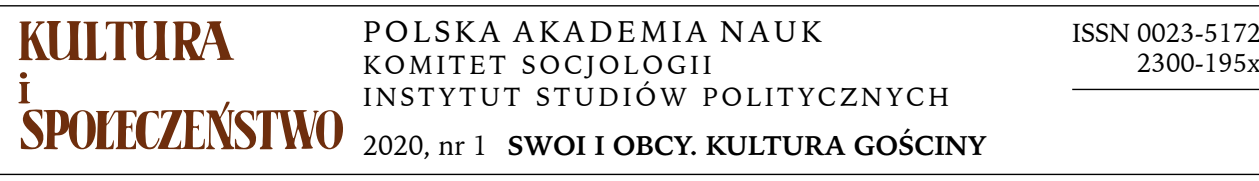
$\begin{array}{llllllll}A & R & T & Y & K & U & 亡 & Y\end{array}$
I
$\begin{array}{llllllll}\mathrm{R} & \mathrm{O} & \mathrm{Z} & \mathrm{P} & \mathrm{R} & \mathrm{A} & \mathrm{W} & \mathrm{Y}\end{array}$

ARIEL MODRZYK

Uniwersytet im. Adama Mickiewicza

\title{
SAMOOGRANICZAJĄCA SIĘ TOWARZYSKOŚĆ ŻYWNOŚĆ, ALKOHOL I KAWA ORAZ TRZY ZASADY Z EKONOMKI GOŚCINNOŚCI
}

Gościna to sytuacja, w której dochodzi do udostępnienia własnej przestrzeni, gospodarstwa domowego oraz zasobów innym aktorom społecznym. Poszukając korzeni pojawiającej się wówczas gościnności, można sięgnać do problematyki terytorializmu. Opisywany przez Konrada Lorentza (1996, s. 101-105) zwyczaj wręczania „fajki pokoju”, który — jego zdaniem — miał służyć ograniczaniu niepotrzebnej agresji, może być traktowany jako zalążkowa forma gościnności, rozumianej jako przyzwolenie na to, aby „obcy” mógł przebywać „u mnie”. Zgodnie z zarysowaną ramą gościnność jest zalegitymizowaną przez gospodarza obecnością innych na jego własnym terenie ${ }^{1}$. Na tym ogólnym poziomie rozważań gościnność ma charakter pokojowy, choć nie bez potencjalnych konfliktów i władzy, które mogą pojawić się $\mathrm{w}$ trakcie współbytowania. Chciałbym opisać jeden z wymiarów takiego wzajemnego napięcia - ekonomikę życia $\operatorname{cod} z i$ ennego. Nie jest ona powiązana $z$ modelem homo economicus, co mogłaby sugerować nazwa. Raczej składa się z reguł, które uwzględniają pewną dozę kalkulacji, wyważania wartości i wymagań, projektowania oczekiwanych scenariuszy, miarkowania i oceniania, czy mamy do czynie-

Adres do korespondencji: arlmodrzyk@gmail.com; ORCID: 0000-0002-5075-4180

${ }^{1}$ Bliskość znaczeniową wrogości i gościnności odzwierciedlają angielskie terminy mające wspólny źródłosłów: host (gospodarz), hospitability (gościnność) i hostility (wrogość) (Skowrońska 2019, s. 97). 
nia $z$ nadmiarem lub niedoborem gościnności, a przede wymagają ustalania, co jest normą ${ }^{2}$. Materialnym punktem odniesienia dla takich ewaluacji są między innymi żywność, alkohol oraz kawa ${ }^{3}$. Opiszę dalej trzy reguły: „lepiej więcej niż za mało”, „lepiej mniej niż za dużo” oraz „przynajmniej”. Sposoby mierzenia tego, czy podczas gościny jest czegoś za dużo lub za mało, mają charakter jakościowy i kontekstualny. Do tego opisu służą zatem takie terminy jak: „dużo”, „mało”, „więcej”, „mniej”, „W sam raz”. Nie ma bowiem jednej i obiektywnej miary na przykład tego, ile alkoholu powinno się wypijać w gościnie. Jest to „wielkość” negocjowana pomiędzy uczestnikami. Tutaj ilościowy aspekt pieniężny związany z trzema branymi pod uwagę elementami gościnności - czyli żywnością, alkoholem i kawą nie będzie szczegółowo rozważany. Oczywiście zasoby pieniężne bywają uruchamiane niewłaściwie (w zbyt dużym lub zbyt małym zakresie), co wprowadza napięcie między gośćmi a gospodarzami. W takich sytuacjach oceny zachowań pieniężnych mogą zostać uwikłane w klasyfikacje powiązane $z$ wymiarem klasowym (Bourdieu 2006, s. 634-650; 2009, s. 36-46). Wówczas mogą zostać użyte etykietki ostentacyjnej konsumpcji (Veblen 1998) - skąpego lub rozrzutnego bogatego czy szczodrego biednego. Zamiast klasowego i pieniężnego wątku skupię się na zasadach, które choć mogą mieć klasowe kontekstualizacje, pojawiają się przy gościnnych stołach różnych grup społecznych.

W rozważaniach zastosowałem perspektywę socjologii życia codziennego (Drozdowski 2010, 2012) wpartą trzema teoriami, które kierują uwagę na różne aspekty warunkujące ekonomikę gościnności. Po pierwsze, jest to teoria ram pierwotnych Ervinga Goffmana (2006a). Zgodnie z nią uczestnicy interakcji próbują ustalić wspólną definicję sytuacji, w której uczestniczą. Podzielanie ram sytuacji gościnności jest bardzo ważne dla udanego jej przebiegu. Analiza elementów otoczenia materialnego gościnności - żywność, alkohol, kawa - ułatwiają wspólne odczytywanie statusu spotkania. Po drugie, jest to teoria wymiany Petera Blaua (2006). Gościnność z tej perspektywy jest swoistą wymianą społeczną, w której przedmiotem są dobra zarówno symboliczne, jak i materialne. Najważniejszym aspektem, na który warto zwrócić uwagę w tym kontekście, jest ocena gościnności z perspektywy przekonań zwią-

\footnotetext{
${ }^{2}$ Normę rozumiem jako zbiór reguł, które określają wzory odpowiedniego postępowania i zachowania się. W takim ujęciu norma może być kontekstualizowana, co prowadzi do zróżnicowanych praktyk. Na przykład norma dobrej gościnności może być wypełniana różnymi treściami w zależności od typu spotkania oraz grupy społecznej.

3 Ważnym materialnym punktem odniesienia podczas gościny jest również stół (zob. Krajewski 2019, s. 19-50.
} 
zanych z moralnością społeczną. Brak uzgodnienia oczekiwań dwóch stron i ustalenia wspólnej definicji sytuacji gościny może spowodować, że niektóre gesty zostaną uznane za dowód braku szacunku. Po trzecie, jest to teoria łańcuchów rytuałów interakcyjnych Randalla Collinsa (2011). Zgodnie $z$ jej założeniami gościnność można potraktować jako formę rytuału, podczas którego wytwarza się wspólna energia emocjonalna. Nieudane rytuały gościnności cechuje brak odpowiedniej, wzajemnej rytmiki gestów oraz dostrojenia energetycznego i emocjonalnego uczestników. Wszystkie trzy wymienione teorie zazębiają się. Na przykład brak wspólnej definicji sytuacji może skutkować uznaniem wymian dóbr symbolicznych i materialnych podczas gościnności za niewłaściwe („oczekiwałem, że nas lepiej ugości, a przygotował tylko kawę”) oraz brakiem dostrojenia i wytworzenia wspólnej energii emocjonalnej („upił się i nie mogłem się z nim dogadać").

\section{METODOLOGIA BADAŃ}

Opis zasad ekonomii codzienności opieram na badaniach będących częścią grantu Narodowego Programu Rozwoju Humanistyki „Archiwum Badań nad Życiem Codziennym" (2014-2019) ${ }^{4}$. Zostały one przeprowadzone w latach 2017-2018 w trzech małych miastach (do 50 tysięcy mieszkańców) zachodniej Polski. W 2017 roku został ogłoszony konkurs pamiętnikarski dotyczący tematyki gościnności. Ponadto siedmioosobowy zespół zrealizował 58 indywidualnych wywiadów pogłębionych i jeden z parą (w tym czternaście przeprowadzonych przeze mnie). Rozmówców dobierano $z$ uwzględnieniem takich cech jak: wiek, płeć, wykształcenie i wykonywany zawód. Wywiady miały służyć odtworzeniu codziennych i odświętnych praktyk związanych z gościnnością, sposobów pełnienia roli gościa i gospodarza oraz znaczeń, które wiąże się z gościną. Cytaty zaczerpnięte $z$ tego badania będę określał jako „wywiady-gościnność”. Drugim źródłem danych, pośrednio dotyczących gościnności, są przeprowadzone w latach 2013-2015 indywidualne wywiady pogłębione dotyczące praktyk wyrzucania żywności i normy niemarnowania żywności. W toku tych badań zrealizowałem 68 wywiadów z pracownikami organizacji, w których wyrzuca się żywność, oraz z przedstawicielami różnych kategorii gospodarstw domowych dobranych pod względem dochodu, miejsca zamieszkania i sposobu zaopatrywania się w żywność (rynek, śmietniki, pomoc żywnościowa, własne uprawy i hodowla). Cytaty z tej grupy wy-

\footnotetext{
${ }^{4} \mathrm{Nr}$ grantu 0027/NPRH2/H11/81/2012.
} 
wiadów opatruję mianem „wywiady-żywność”. Oprócz źródła wywiadów $\mathrm{w}$ ich opisach będę podawał również płeć, wiek respondentów (w przedziałach: >20, 20-30, 30-40, 40-50, 50-60, <60), wykształcenie (podstawowe, zawodowe, średnie, wyższe), zawód oraz miejsce zamieszkania (wieś, miasto do 50 tys. mieszkańców [>50 tys.], miasto powyżej 500 tys. mieszkańców [<500 tys.]). Wypowiedzi respondentów będę odróżniał od pytań badaczy („B”) kodem „R”. Wywiady były analizowane metoda kondensacji oraz interpretacji sensu (Kvale 2011, s. 196-199). Analizie została poddana mała część materiału badawczego. W przypadku wywiadów o gościnności korzystałem $z$ fragmentów poświęconych przygotowaniom żywności oraz spożywaniu kawy i alkoholu, a z wywiadów na temat marnotrawstwa żywności wydrębniłem tylko te wątki, w których podejmowany był temat ustalania odpowiedniej ilości żywności na spotkanie gościnne. Próbowałem odpowiedzieć na następujące pytania badawcze:

W jaki sposób aktorzy społeczni negocjują podczas gościny spożycie żywności, alkoholu i kawy?

Jak przez pryzmat żywności, alkoholu i kawy spożywanych w gościnie definiowana jest odpowiednia gościnność?

Jak te definicje odnoszą się do przekonań dotyczących polskiej gościnności?

ŻYWNOŚĆ PODCZAS GOŚCINY I ZASADA „LEPIEJ WIĘCEJ NIŻ ZA MAŁO”

Jednym z zasobów gospodarza najczęściej udostępnianych gościom jest żywność i przygotowane potrawy. Spotkania wokół żywności mogą mieć formę obiadu w małym, bliskim gronie, większych przyjęć z okazji świąt okolicznościowych (urodziny, rocznice) lub imprez w wynajętym lokalu (stypy, śluby, komunie, urodziny). Zasadą, która dominuje podczas przygotowywania żywności na takie okazje, jest: „lepiej więcej niż za mało” ${ }^{5}$. Opiera się ona na dążeniu do obfitości, co wynika z lęku przed ewentualnym niedoborem, który może powodować, że gospodarz w oczach gościa zostanie uznany za „chytrego”, „niegościnnego” lub nieumiejętnie organizującego wspólne spotkania.

R1 [K, 40-50, średnie, rencistka, wieś]: I robię zawsze na zapas [...] żeby nie zabrakło. [...] Żeby starczyto na święta i jeszcze zostało.

${ }^{5}$ Zasada ta dominuje również w innych kontekstach, takich jak przygotowanie odpowiedniej ilości produktów w supermarketach i zapasów w restauracjach oraz robienie codziennych zakupów w gospodarstwach domowych. 
R2 [M, >20, uczeń szkoły średniej, wieś]: Żeby ktoś przy stole nie powiedziat, że, nie ma. A to też tak jest, że jak goście przyjada, trochę więcej zrobimy [...] [śmiech wszystkich]. To taka tradycyjna polska gościnność.

R1: Na wszelki wypadek.

R2: Na wszelki wypadek. [wywiady-żywność]

Generalnie bycie w kuchni mi nie sprawia przyjemności. Ale jak już robię, to robie dosyć sporo tego jedzenia. Zawsze zostaje mi na caty tydzień po gościnie. [...] nie potrafię sobie obliczyć, żeby byto na styk. Zreszta wole, żeby zostało, niż miatoby zabraknać i coś trzeba bytoby dorabiać. [wywiady-gościnność, K, 40-50, średnie, miasto $>50$ tys.]

Najbardziej zwracam uwagę na to, żeby nikomu niczego nie brakowało. Taka zasada kierujemy się $w$ domu. [wywiady-gościnność, $\mathrm{K},>20$, uczennica szkoły średniej, miasto $>50$ tys.]

Niedobór jest równoznaczny z poczuciem dyskomfortu u gościa, a to jest coś, czego należy unikać. Choć gość zgodnie z etykietą powinien zaakceptować taki stan rzeczy, jednak doświadczenie własne dotyczące takich sytuacji, zakulisowe dzielenie się plotkami na ich temat staje się powodem napięcia i potwierdza założenie, że nie można doprowadzić do braku ${ }^{6}$.

Bardzo często na wesela zamawiaja po cztery porcje. Ja tłumaczę każdemu, że naprawdę trzy w zupetności na osobę cieple mięsa. [...] No więc ja mówię, że trzy już jest wystarczająca ilość. [...] Ale oni uważaja, że nie, bo gdzieś na weselu byli i zabrakło. No, może tam mniej zamówili. [...] Ale nie wszyscy stuchaja. [...] „Żeby nie zabrakło”, jeżeli chodzi o wesela, „żeby mnie nie obgadali, że zabrakło jedzenia”. [wywiady-żywność, K, 50-60, właścicielka firmy cateringowej]

Zasada „lepiej więcej niż za mało” dowodzi, że rzadko „jest w sam raz”. Optymalne planowanie w sytuacji gościny często jest niemożliwe, gdyż trudno przewidzieć, kto, ile i co będzie chciał zjeść. Zgodnie z duchem teorii wymiany Blaua (2006) można powiedzieć, że racjonalna kalkulacja jest wówczas niewskazana, ponieważ zdominowałaby założenie o autoteliczności wspólnych spotkań. Z dwóch negatywnych scenariuszy — nadmiaru i niedoboru żywności — wybiera się „mniejsze zło”, czyli nadwyżkę.

Gościnność sprawia, że wiele aspektów życia codziennego, zobowiązań, form aktywności (praca, codzienne obowiązki, własne pasje) zostaje zawieszonych na pewien czas. Reguła „lepiej więcej niż za mało” wraz $z$ trwaniem gościny zaczyna współwystępować z dwiema innymi kwestiami. Z jednej strony obficie zastawiony stół nieuchronnie staje się proble-

${ }^{6}$ Oczywiście brak żywnościowy jest jedną z wielu możliwości odczuwania nieprzyjemnych uczuć przez gościa, obok takich jak: zachowanie psa gospodarza, jego dzieci, wulgarność po alkoholu, zasady odmienne od panujących we własnym domu. 
matyczny z powodu różnorodnych diet, samodyscyplinowania cielesnego, lęku przed przytyciem lub zjedzeniem czegoś, co zaszkodzi zdrowiu. Z drugiej strony pod koniec spotkania i później pojawia się zobowiązanie moralne do niemarnowania żywności, które podczas przygotowywania potraw na spotkanie $z$ gośćmi zazwyczaj pozostaje na drugim planie, zdominowane przez chęć pokazania się jako gościnny gospodarz. Z czasem zaczyna ono odgrywać coraz większą rolę i chęć zadośćuczynienia wymogowi dobrego gospodarowania żywnością idzie wówczas $\mathrm{w}$ parze $\mathrm{z}$ gościnnością w postaci wydawania jedzenia.

My na przykład jak tutaj robimy wigilię u nas, no to przyjeżdża rodzina, to dostaje też do domu. Trochę każdy coś dostaje, ten dojezdny. Żeby też miała na następny dzień, żeby zjeść. [...] raczej z reguly wydajemy, no i dojadamy sami. [wywiady-żywność, K, 20-30, wyższe, bezrobotna, wychowuje dzieci w domu, wieś]

Jeżeli mimo wszystko zostaje duża nadwyżka, to wdraża się praktyki konserwacji (najczęściej mrożenie] i intensywnego zjadania przygotowanej żywności (np. codzienne obiady na bazie potraw z przyjęcia).

Zasada „lepiej więcej niż za mało” ewoluuje wraz z kolejnymi doświadczeniami w organizacji przyjęć. $Z$ biegiem lat nawyki zmieniają się w kierunku większego umiaru — szykuje się mniej jedzenia.

Tak więc dosyć lajtowo podchodzimy do tego i nie staramy się na site, żeby było tam 12 potraw [...] po prostu jest tak trochę na luzie, nie? Że nie ma tej spiny [wywiady-żywność, K, 20-30, wyższe, social media manager, miasto <500 tys.]

Ja na początku robiłam za dużo tych ryb, wszystkiego. W tej chwili już nie, w tej chwili robię mniejsze ilości i głównie to, co naprawdę wiem, że zjemy. Ale z poczatku to się wyrzucato. [...] i co roku mówimy ,no już za rok mniej, mniej”. No niby robimy mniej, ale to jeszcze nie jest tak, żeby... [śmiech]. [wywiady-żywność, K, 40-50, średnie, pracownik produkcyjny, wieś]

W pojedynczych przypadkach wręcz zamieniano wcześniejszą zasadę na „lepiej mniej niż więcej” podkreślając, że potencjalne niedobory są lepsze niż nadwyżka żywnościowa. Co ciekawe, takie zmniejszenie zakresu ostrożności rzadko powoduje braki, ponieważ w gospodarstwach domowych zazwyczaj są awaryjne zapasy w postaci żywności mrożonej, szafki ze słodyczami. Pożycza się też żywność od sąsiadów lub kupuje szybko w sklepie.

Zasada „lepiej więcej niż mniej” koresponduje z regułą występującą w polskiej kulturze „zastaw się, a postaw się”. Większość respondentów jednak dystansowała się wobec niej. Nasuwa ona bowiem skojarzenia z utracjuszostwem, niepotrzebną ostentacją, chęcią pokazania za wszelką cenę swojego statusu. 
Ja nie lubię tego „a zastaw się”. Nie lubię nad stan. I mówię, nie cierpię jak ktoś żyje nad stan. [wywiady-gościnność, K, 40-50, zawodowe, bezrobotna, miasto $>50$ tys.]

Sa biedniejsi, którzy naprawdę chca się postawić. Dadza z siebie wszystko. Nawet pożycza, chociaż nie stać, ale chca się pokazać z jak najlepszej strony. Co moim zdaniem jest catkiem niepotrzebne, bo to widać, prawda? Bo to widać. I to jest btędem, takie coś. Powinno się człowieka przyją́ tak, na co mnie stać. [...] nie wymadrzać się, nie wychwalać się, po prostu więcej stuchać, patrzeć, obserwować i dopasować, żeby się ten ktoś dobrze czut. Nie wysilać się za mocno. [wywiady-gościnność, $\mathrm{M}$, 50-60, średnie, pracownik techniczny, miasto $>50$ tys.]

W przypadku przestrzegania reguły „zastaw się, a postaw się” dominuje nie tyle lęk przed niedoborem i troska o dobro gościa, ile próżność i przesadzone, lekkomyślne dążenie do zbytku. W autowizerunku zasada „lepiej więcej niż mniej” jest powiązana z niechęcią do bycia określonym jako osoba skąpa oraz niegościnna, a „zastaw się, a postaw się" z zamiarem pokazania siebie jako osoby, którą stać na wyjątkowy gest, demonstrującej własny sukces materialny. Innymi słowy: „lepiej więcej niż mniej” to umiarkowana i skorygowana forma „zastaw się, a postaw się".

\section{ALKOHOL PODCZAS GOŚCINY I ZASADA „LEPIEJ MNIEJ NIŻ ZA DUŻO”}

Według wielu osób „prawdziwa” gościnność jest związana z dostępnością alkoholu. W szczególności jest on istotny podczas gościny, którą można określić jako niecodzienną — jako spotkanie w gronie rodzinnym i/lub przyjacielskim z wyjątkowej okazji, stanowiące pewien przerywnik w rutynie codziennej pracy i obowiązkach. Obecność określonego alkoholu często definiuje rodzaj uroczystości. Na weselach dominuje wódka, choć coraz częściej pojawia się też wino i piwo. Natomiast podczas grilla najwięcej wypija się piwa. „Spotkanie na piwie” jest minimalistyczną formą spotkania alkoholowego. Ta mało wymagająca forma gościnności sprawia, że można ją praktykować w każdym dniu tygodnia. Najczęściej jednak o alkoholu wspominano w kontekście spotkań, które nakładają na obie strony - gości i gospodarzy - więcej wymagań. Alkohol zatem zazwyczaj jest utożsamiany z gościnnością zakłócającą życie codzienne, wymagającą przygotowania specjalnych potraw, zarezerwowania większej ilości czasu, chwilowego zawieszenia innych zobowiązań.

Jakie są zalety alkoholu na imprezach? Pełni on funkcje integrujące. Mówiono o tym, że alkohol „rozwiązuje język”, pozwala przełamać sztywność sytuacji gościny, ogranicza momenty krępującej ciszy. 
Na pewno, alkohol trochę rozluźnia sytuację. Bo wiadomo, z początku to wszystko jest takie spięte. No to, no, buch, po jeden, drugi, i już tutaj człowiek staje się bardziej taki wyluzowany. Już nie krępuję się podjaććjakiegośtematu [wywiady-gościnność, $\mathrm{M},<60$, średnie, pedagog specjalny, miasto $>50$ tys.]

Alkohol przyczynia się do większej spontaniczności zachowań, takich jak wspólne ożywione dyskusje, podnoszenie głosu, śpiewanie, tańce. Wprawia ciała w ruch, daje większą swobodę i podwyższa energię emocjonalną grupy (Collins 2011). Wskazywano również, że pod jego wpływem robi się rzeczy „zabawne”, „śmieszne”, odświętnie, nagina się normy społeczne i poszukuje ich granic, co sprzyja wytwarzaniu opisywanych przez Petera Bergera i Thomasa Luckmanna (1983) „obszarów ograniczonego znaczenia".

Co ciekawe, jednak większa część respondentów z dystansem, często wręcz negatywnie, odnosiła się do alkoholu. Choć dla odpowiedniego przebiegu wielu spotkań jest on niezbędny, może być zarazem niebezpieczny. Można wskazać trzy sytuacje, w których alkohol staje się problemem. Pierwsza, najczęściej wspominana, to brak kontroli nad własnym zachowaniem i ciałem, czyli to, co Goffman (2006a) określał jako „fuszerkę”. Może mieć formę „nadmiaru” energii i ekspresji lub niedoboru energetycznego, skutkującego tym, że gość zasypia lub przedwcześnie udaje się do domu. Powstaje niedopasowanie energetyczne oraz brak dostrojenia rytmiki gestów, co skutkuje zaburzeniem wspólnego rytuału. Naginanie norm społecznych po alkoholu może być czymś zabawnym, ale też jest określane jako „wulgarne”, „godne pożałowania”, „żenujące”. Może być wstydliwe dla nietrzeźwego po imprezie, a w jej trakcie dla osób towarzyszących. Pod wpływem alkoholu porusza się tematy niewskazane i dzielące zebranych, takie jak polityka i religia. Osoby pijane są skłonne do kłótni, „momentów szczerości”, które powodują rozłam we wspólnocie gościny ${ }^{7}$.

[...] jak spotykamy się z kolegami gdzie dwóch, trzech wariatów na punkcie sportu, no to pitka, reprezentacja [...]. A mam też takich kolegów z pracy, którzy się nie interesuja pitka, no to się zawsze gdzieś na temat wojska wjedzie, a jak temat wojska, no to zaraz polityka się do tego wkrada, minister taki, za tamtego byto lepiej, ten dat podwyżki. [...] Ja staram się nie rozmawiać po alkoholu o kościele i polityce, bo ja wolę na trzeźwo o tym porozmawiać, bo wtedy ta dyskusja donikąd nie prowadzi, a łatwo można się pokłócić, co prawda się jeszcze nie zdarzyto, ale wole unikać takich tematów. Wolę neutralne tematy, o sporcie pogadać, gdzie tam kto pracuje, jak tam się żyje i tak dalej. [wywiady-gościnność, M, 40-50, średnie, dziennikarz, miasto $>50$ tys.]

7 Jest to jeden $z$ wielu przykładów napięć powstających w konwersacji podczas gościny (Mateja-Jaworska 2019, s. 69-76, 83-93). 
Drugi kontekst problematyczności alkoholu to namawianie do picia. Osoby niepijące wskazywały, że może mieć formę nieprzyjemnej, czasami napastliwej presji. Jeśli nie wystarcza asertywności, to w takiej sytuacji najczęstszymi wymówkami są konieczność prowadzenia samochodu lub zajmowania się dziećmi.

Różnie bywało. Jedni „o, jesteś, siadaj” ijuż kielicha. „Nie, dziękuję”. „Co ty cholera, nie pijesz? Co z toba się dzieje", o takie o! [...] to przestałem chodzić. [wywiady-gościnność, $M,<60$, zawodowe, emeryt, miasto $>50$ tys.]

Ale ja mówię „nie pije”. [...] "a nie pijesz to kablujesz", takie powiedzenie w Polsce jest. [wywiady-gościnność, $M,<60$, średnie, emeryt, miasto $>50$ tys.]

Inna źle wspominana konsekwencja picia alkoholu to „przeciąganie liny" podczas zamknięcia wspólnego spotkania. Osoby pijane mają większą skłonność do jego przedłużania.

„Siadaj, no co ty, siadaj! Daj se spokój! Przestań, siadaj. No na chwile — jeszcze 15 minut”. Na tej zasadzie. „No dobra, zaraz pójdziesz”. No tak, przeciaganie. [wywiady-gościnność, K, 30-40, wyższe, kierowniczka, miasto >50 tys.]

Podwyższony poziom energii emocjonalno-cielesnej często jest uwarunkowany spożyciem alkoholu. Zawód z powodu niemożności wytracenia tej nadwyżki skutkuje próbami wydłużania wspólnych uroczystości. Pijany gospodarz namawia, aby pozostać w jego domu, a nietrzeźwemu gościowi trzeba komunikować konieczność zakończenia spotkania. Niedostymulowanie oraz nadwyżka energetyczna, która nie została zużyta, kojarzą się z niedoborem gościnności. Odczucia cielesne i emocjonalne mogą też służyć do miarkowania nadmiaru gościnności, na który reakcją jest znużenie, ziewanie, chęć pójścia spać. Zmęczenie gościnnością często jest ostatecznym argumentem za tym, aby zakończyć spotkanie.

Mówiąc o alkoholu przeważnie podkreślano zatem niebezpieczeństwa z nim związane. Zasadę, która za tym stała, można określić jako „nie za dużo” lub „lepiej mniej niż za dużo”. Zgodnie z normatywnym założeniem gospodarzy gościna jest więc uschematyzowaną sytuacją społeczną, a kontrola jej odpowiedniego przebiegu może być zakłócona przez nadmiar alkoholu. Zasada „nie za dużo” zaś wskazuje, że oczekiwaną postawą jest umiar, samokontrola ustanawiająca granicę między „piciem” a „uchlewaniem się".

Tylko po jakimśs piwie tam sobie. To nie jest wódka, tak? To nie sa jakieś winiacze, tylko po prostu po piwie sobie wypija. To mi nie przeszkadza, bo też uchlewania się na umór to ja tego nie, nie. [wywiady-gościnność, K, 20-30, wyższe, pracownica ośrodka pomocy dla niepełnosprawnych, miasto $<50$ tys.] 
Osoby zagrażające sytuacji gościny to te, „którym ciągle mało”, zazwyczaj pijani mężczyźni ${ }^{8}$. Alkohol powoduje, że silnie znormatywizowana gościnność jest zaburzona przez to, co „dzikie”, „instynktowne”, „niekontrolowane”, „naturalne” i „zwierzęce” w człowieku, co powinno być przykryte (Elias 1980). Wówczas „puszczają hamulce”, „dostaje się szajbę”, „upodla się”, pojawiają się „prymitywne teksty”, robi się „niesmacznie”, dochodzi do „zaniedbania duchowego”, czyli wszystko, co może być określane mianem „utraty twarzy” (Goffman 2006b, s. 15-47).

A ludzie tym bardziej [...] to zaraz jakaśs szajbę dostaja jak wypija. [wywiady-gościnność, M, 40-50, podstawowe, bezrobotny, miasto > 50 tys.]

Ale ja moge gościć jedzeniem, ale niekoniecznie alkoholem, kiedy wiem, że ten człowiek się upodli. [wywiady-gościnność, K, 30-40, średnie, prowadzi sklep, miasto $>50$ tys.]

Alkohol może być problematyczny w takim stopniu, iż niektórzy respondenci mówili, że preferują spotkania bezalkoholowe lub że alkoholu $\mathrm{u}$ nich nie ma. Często pojawiał się jednak zwrot „da się bawić bez alkoholu” albo „pojawia się on symbolicznie”. Wyrażenia te sugerują, że obecność alkoholu na imprezach jest nadal normą i trzeba dowodzić, że jest możliwe - że „się da” - miło wspólnie spędzić czas bez niego:

[...] niektórzy twierdza, że im więcej alkoholu tym lepsza impreza, ale to nieprawda. Można też się dobrze bawić bez alkoholu, nie musi być dużo alkoholu, żeby się dobrze bawić. [wywiady-gościnność, M, 40-50, średnie, dziennikarz, miasto $>50$ tys.]

Nie ma też tak, że jak nie ma alkoholu, to przyjęcie się nie odbędzie. Tak, że tutaj można powiedzieć, że jesteśmy na takim poziomie, z którego ja się cieszę. [wywiady-gościnność, $\mathrm{K},<60$, wyższe, pielęgniarka, miasto $>50$ tys.]

Bo ja nawet bez alkoholu potrafię się dobrze bawić [...]. W każdym razie no mi nie trzeba alkoholu, żeby się dobrze bawić, bo jestem wesoła osoba i lubię wesołe osoby. [wywiady-gościnność, K, 30-40, wyższe, nauczycielka, miasto >50 tys.]

Wyjątkowość spotkania warto jednak podkreślić przynajmniej „symboliczną” ilością alkoholu. „Nie za dużo” to na przykład ,jeden kieliszek”. Dominuje wówczas nastawienie na smakowanie, delektowanie się małą ilością lepszego alkoholu, takiego jak nalewka własnej roboty, droższe wino lub piwo. Ukierunkowanie na przełamywanie napięcia lub aspekty zabawowe przechodzą wtedy na drugi plan.

\footnotetext{
8 Oprócz nietrzeźwych mężczyzn jako podmioty, które potencjalnie mogą zakłócić swoim zachowaniem gościnę, wymienia się dzieci i wolno biegające po domu zwierzęta (zwłaszcza psy). (Modrzyk 2019, s. 152-156; Małkowicz-Daszkowska 2019 s. 175-192, s. 183-185).
} 
Dominującą zasadę w przypadku żywności, czyli „lepiej więcej niż za mało", ustalają gospodarze tuż przed spotkaniem, podczas przygotowań. Natomiast kluczowa dla spożycia alkoholu reguła „lepiej mniej niż za dużo" jest negocjowana przez cały czas trwania spotkania, $z$ włączeniem strony gości, którzy mogą nieśmiało proponować zwiększenie jego spożycia lub muszą bardziej zdecydowanie go odmawiać. Spożycie alkoholu w trakcie spotkania może wpłynąć na zmiany wcześniejszych założeń dotyczących granic jego konsumpcji. Aktywna rola gościa w ustalaniu ilości alkoholu niekiedy przejawia się $\mathrm{w}$ postaci prezentu, co może być odczytane jako zaproszenie do wymiany społecznej, w której gospodarz powinien zrewanżować się otwarciem otrzymanej butelki. Narusza to często normatywne roszczenie gospodarza do kontroli nad definicją sytuacji gościny i ustanowioną normą „lepiej mniej niż za dużo” alkoholu.

$W$ taki sposób się przejawia, że chociaż naleweczkę przyniesie w kieszeni [...]. I to mnie drażni osobiście. [...] Za każdym razem, albo jeszcze mi przyniosa, co mnie denerwuje. Ja po pewnym czasie to wyrzucam, bo sama nie piję. Jeśli komuś nie wcisne innemu, to wyrzucam. [wywiady-gościnność, $\mathrm{K},<60$ ]

Dla alkoholików to nie mam taryfy ulgowej. Mam męża alkoholika, ale ja zrobitam wszystko, żeby mu pomóc. Żeby on nie pił. Ale on nie zrobit nic. I dlatego tutaj jestem wrogo nastawiona, bo ja uważam, że to nie jest choroba taka, żeby jej nie można wyleczyć. [wywiady-gościnność, K, 40-50, zawodowe, bezrobotna, miasto $>50$ tys.]

Nieufne nastawienie wobec alkoholu sugeruje upowszechnianie się oporu wobec nadmiernego picia podczas spotkań towarzyskich. Dążenie do zmniejszania ilości wypijanego alkoholu może wynikać również z prób przepracowania powszechnego doświadczenia alkoholizmu w polskich domach. Doniesienia medialne mogą jednak sugerować, że teza o dominacji nastawiania na umiar i ograniczaniu konsumpcji alkoholu jest błędna:

„Statystyczny Polak wypija rocznie blisko 11 litrów czystego spirytusu. Pijemy coraz więcej i coraz częściej, a duży wpływ na rosnącą konsumpcję ma popularność «małpek», czyli butelek o pojemności 100-200 ml. Z badania Synergion wynika, że codziennie kupuje je 3 miliony osób, a ponad 600 tys. klientów co najmniej dwa razy w ciągu dnia. — Jeśli przyjmiemy, że nasze szacunki pokazują około $3 \mathrm{mln}$ nabywców czy spożywających dziennie, a rok ma 365 dni, to choć prawdopodobnie nie wszystkie dni są aż tak intensywne pod względem spożycia, to roczna sprzedaż tego formatu alkoholu sięga miliarda butelek" ${ }^{9}$.

9 Alarmujące dane. Po „matpki” codziennie sięga 3 miliony Polaków, „Wprost”, 7 kwietnia 2019 (https://www.wprost.pl/kraj/10206053/alarmujace-dane-po-malpki-codzienniesiega-3-miliony-polakow.html [dostęp: 05.10.2019]). 
Bardzo duże spożycie „małpek” niekoniecznie jednak stoi w sprzeczności z tym, że ogranicza się obecność alkoholu podczas spotkań gościnnych. Małe butelki wódki są przeznaczone na szybkie i indywidualne spożycie. Raczej nie pojawiają się na stole podczas gościny. Dane Państwowej Agencji Rozwiązywania Problemów Alkoholowych również nie pozwalają stwierdzić, że dystansowanie się wobec alkoholu podczas spotkań gościnnych jest papierkiem lakmusowym spadku jego konsumpcji. Od lat dziewięćdziesiątych XX wieku do końca drugiej dekady XXI spożycie czystego alkoholu w przeliczeniu na osobę w Polsce wzrosło średnio o około trzech litrów (z 6,52 w 1993 r. do 9,55 w 2018 r.) ${ }^{10}$. Można przypuszczać, że nadmierne picie alkoholu zostało przesunięte ze spotkań gościnnych w szerszym gronie, mających bardziej publiczny i otwarty charakter, ku sferze prywatnej. Próby zmniejszania ilości alkoholu na imprezach raczej oznaczają zmianę postaw wobec uznawanego wzoru jego konsumpcji niż rzeczywiste zmniejszenie skali spożycia. Teza o przesunięciu normatywnym $\mathrm{w}$ postaci zmniejszonego przyzwolenia na picie dużej ilości alkoholu na spotkaniach towarzyskich musiałaby zostać sprawdzona w dalszych badaniach. Zasada „lepiej mniej niż więcej” to jedna z poszlak sugerujących, że taka zmiana następuje.

\section{„PRZYNAJMNIEJ” KAWA I ZASADA „MINIMUM” GOŚCINNOŚCI}

Gościnność zorganizowana wokół kawy ma zupełnie inny charakter niż uroczystości w liczniejszym gronie, podczas których spożywa się alkohol. Oczywiście przy kawie także można spotkać się w większej grupie, lecz zwykle dzieje się tak podczas niezapowiedzianych i spontanicznych wizyt rodziny, gdy gospodarz nie jest odpowiednio przygotowany. Czas na kawę może być również częścią dużych uroczystości, takich jak wesele. Jednak najpowszechniejszą formą spotkania przy kawie są intymne rozmowy w cztery oczy. W przypadku takich interakcji kawa jest materialną podstawą ramy pozwalającej na odczytanie wspólnej definicji sytuacji. Tak jak alkohol jest symbolem przede wszystkim większych uroczystości, wyjątkowych, mających bardziej publiczny charakter, tak kawa to fundament małych, codziennych i intymnych interakcji. Formę podobną do spotkania przy kawie ma spotkanie „na herbacie”, „na piwo” lub „na papierosa”. Łączy je minimalistyczna otoczka gościnności, która nakłada na gospodarza mało zobowiązań. Wystarczy „tylko” zrobić kawę, postawić piwo lub zapa-

10 Państwowa Agencja Rozwiązywania Problemów Alkoholowych (https://www.parpa.pl/ index.php/badania-i-informacje-statystyczne/statystyki [dostęp: 02.31.2020]). 
lić papierosa i zarezerwować niewiele czasu. Kawę można uznać za symbol minimalistycznej formy gościnności, ponieważ zdecydowanie najczęściej respondenci o niej wspominali.

Otaczająca infrastruktura usługowa ma wpływ na to, w jakim miejscu spożywa się kawę. Respondenci z małych miasteczek spotykają się zazwyczaj w domach, gdyż nie ma kawiarni w ich lokalnym otoczeniu. W dużych miastach natomiast na kawie można się spotkać na „neutralnym gruncie”, co pozwala jeszcze bardziej wyjść poza ramę sytuacji gościny oraz podział ról na gościa i gospodarza. O popularności takich spotkań może świadczyć duża liczba kawiarni i małych punktów, w których można wypić kawę. Oprócz przestrzeni spotkania przy kawie warto zwrócić uwagę na perspektywę temporalną, która jest z nią związana. Standardową kawę opisuje się jako spotkanie trwające od około trzydziestu minut do dwóch godzin. Domowa kawa sporadycznie się przedłuża i może przerodzić się w długie nocne rozmowy oraz wymagać przygotowania posiłku.

Alkohol pojawia się na imprezach w połączeniu $z$ obiadami i specjalnie przygotowanymi potrawami, kawa zaś nie wymaga tego. Kawę łączy się ze słodkościami - ciastkami, cukierkami oraz ciastem. Minimum gościnności wymaga zatem posiadania w domu zapasu kawy i ewentualnie słodyczy. Kawa jest „kołem ratunkowym”, umożliwiającym szybkie reagowanie na nieprzewidziane spotkania i wizyty. Mało wymagająca forma spotkania na kawie sprawia, że uwaga uczestniczących w nim nie jest nakierowana na otoczkę gościnności (jakość potraw, przygotowanie wnętrza domu, odpowiednie ubranie się, kupienie prezentów itd.), lecz na to, co kluczowe i centralne w osobistym kontakcie, czyli wspólne spędzenie czasu oraz rozmowa. Wszystko to sprawia, że „kawa” to pole do spontanicznych spotkań między jednostkami. Oddają to wyrażenia świadczące o dynamiczności i szybkości podejmowania decyzji o kawie, takie jak „wpaść na szybko”, „zrobić od razu".

Nie, bo to jest na takiej zasadzie, że ona dzwoni i mówi „zrób mi małą kawę, ja już jade!". Szybko pijemy, ona opowiada co tam u niej, rozmawiamy co w przedszkolu izaraz ucieka, bo ona też ma obowiązki. Tak samo jest, jak ja jadę do niej. [wywiady-gościnność, K, 30-40, średnie, sprzątaczka, miasto > 50 tys.]

Często jest tak spontanicznie [...] jak ktośchce, to sobie przyjdzie, tak? Zadzwoni do mnie: „stuchaj, wpadam na kawę” [...]. Czasami mówię: „siedz̨ w domu, przyjdź na kawę". [...] zazwyczaj tak jak mówię, bratowa męża też dzwoni: „stuchaj, jutro będęw twojej okolicy”, „dobra, to przychodź na kawę”. [wywiady-gościnność, K, $30-40$, wyższe, doradca finansowy, miasto $>50$ tys.]

Kawa często jest przedłużeniem przypadkowego spotkania na mieście, przejazdu przez okolicę zamieszkaną przez znajomą, przejścia obok miesz- 
kania koleżanki, która zaprasza na kawę ze swojego balkonu. Kawa rozluźnia sztywny podział ról, jaki dominuje w przypadku standardowej sytuacji gościnności. Gość może wprosić się na spotkanie, dzwoniąc i nalegając, aby zaparzono kawę. Podkreślano też, że często to gość sam obsługuje się i szykuje sobie kawę.

Kawę proponuje się też osobom, z którymi łączą nas „słabe więzi” (Granovetter 1973, s. 1360-1380; Nahirny 2015, s. 111-124), czyli remontującym dom, kurierowi, księdzu, pielęgniarce, dalszemu znajomemu. Jako namiastka gościnności kawa jest również wykorzystywana w usługach komercyjnych oraz spotkaniach biznesowych. Klient wypijając kawę może się poczuć dowartościowany. Poprzez kawę wprowadza się pewne ciepło nieformalności w relacji zapośredniczonej przez pieniądz.

Jeszcze w ogóle tak sobie myślę, ci ludzie, z którymi się spotykamy po potudniu, to jest zawsze zwiazzane jednak z jakimś dziataniem, z jakaś korzyścia. Np. jedziemy na kawę do mechanika, do którego oddajemy samochód i mamy go od kilku lat. I przy okazji wypijemy kawę i przy okazji nawiazuja się te relacje. No więc jakby nie idziemy specjalnie na kawę, ale jeśli trzeba zostawić auto, to kawę wypijemy i miło się spotkać. [wywiady-gościnność, K, 40-50, wyższe, urzędniczka, miasto $>50$ tys.]

Kawę wypija się również z bliskimi znajomymi, przyjaciółmi, sąsiadami. Wówczas możliwe są bardziej intymne tematy i plotki, które pozwalają wzmocnić więzi i rozładować napięcia. Kawa staje się zatem krótką przerwą w codziennych obowiązkach. Nie stanowi ona takiego zakłócenia, jak większe spotkania gościnne. Wszystkie cechy kawy dobrze charakteryzują pojedyncze zwroty używane, gdy się ją opisuje, takie jak: „to tylko kawa”, „nic dodatkowego tylko kawa”, „to spotkanie przy okazji” lub „bez okazji”, „bez stresu”, „na spokojnie”.

Jak rodzice powiedza: „,wlecimy na kawę o piatej”, to ja jakieś ciasto zawsze czy kawę, herbatę. I ja wiem, że oni będa na kawę - tak mówiq. Nie przygotowuje nic dodatkowego, tylko wtaśnie takie stodkości jakieś i siedza godzinę, dwie i ida po prostu. I to jest dla mnie takie, bez stresu, przyjda, porozmawiamy i wyjda. To jest dla mnie wtedy takie spokojne. [wywiady-gościnność, K, 20-30, wyższe, miasto $>50$ tys.]

Kawa często oznacza mile widzianą skromność oraz koncentrację na drugiej osobie. Wspominając o niej, dystansowano się od rozwiniętych form gościnności stwierdzając, że „stół nie musi się uginać”. Jako wskaźnik dobrej gościnności wskazywano to, że ktoś robi kawę.

Niekoniecznie stót musi być zastawiony, ale posiedzieć, porozmawiać, pośmiać się. Dla mnie taka jest gościnność. [wywiady-gościnność, K, 40-50, średnie, kosmetyczka, miasto $>50$ tys.] 
Nie ma jakichś tam „zastaw się, a postaw się”, tylko po prostu jak ktoś przychodzi, zrobi się kawę, jakieś ciasto. [wywiady-gościnność, $\mathrm{M},<60$, średnie, muzyk, miasto $>50$ tys.]

Kawę zatem można uznać za pewien minimalny standard gościnności, podstawę przyzwoitości. Wymaganiom narzucanym spotkaniu na kawie powinien sprostać każdy. Ich demokratyczny charakter opiera się na przeświadczeniu, że nie wymagają dużych nakładów pieniężnych i status materialny nie wpływa na możliwość skorzystania z tej ramy w celu organizacji spotkania.

Kawa, herbata to podstawa. [wywiady-gościnność, K, 30-40, wyższe, miasto $>50$ tys.]

Kawę zrobić to nie jest żaden problem, jaki to problem? [wywiady-gościnność, M, $<60$, zawodowe, emeryt, miasto do 50 tys.]

Czy mimo że kawę uznaje się za najmniej zobowiązującą formę gościnności, coś, co można zrobić „na luzie”, podczas takiego spotkania możliwe jest niewypracowanie wspólnej definicji sytuacji? Respondenci twierdzili, że tak. Jeżeli goście są nastawieni na „coś więcej” i otrzymują „tylko” kawę i ciastko, to mogą uznać gospodarzy za skąpych. Takie spotkania określano jako „przy paluszkach”.

Ale nieraz to jest takie, jak to mówiq, że „przy paluszkach" [śmiech], prawda, czy tak skromniutko albo $w$ ogóle nawet [...]. Znam bardzo dobrych ludzi też, znajomych, że imieniny to tak człowiek się nawet czuje tak sprę... Kawkę $w$ kuchni wypijemy. Dziękuje, do widzenia. [wywiady-gościnność, M, 50-60, średnie, pracownik techniczny, miasto $>50$ tys.]

Jeżeli dostrzeże się, że gospodarz robi gorszą kawę i serwuje gorszej jakości słodycze niż na co dzień, to może pojawić się odczucie braku szacunku.

R1 [K, 30-40, wyższe, nauczycielka, miasto >50 tys.]: No kiedyś, pamiętam, mąz opowiadat, że miat takiego kolege, który wtaśnie odwrotnie traktowat — sam pijat dobre kawy, a jak przychodza goście, to wtaśnie już była inna kawa.

R2 [M, mąż, brak danych]: Sknera taki - on mieszkał u babci swojej dziewczyny i mówi „babciu daj tej kawy gorszej dla gości” [śmiech]. Albo fajki, papierosy palit - tymi gorszymi gości częstowat, a lepsze sobie zostawit.

R1: U nas w domu zawsze byto odwrotnie, zawsze jak ktoś miat przyjsś, to starat się człowiek dobrze pokazać, dobrze ugościć [...] [wywiady-gościnność]

Niekiedy zdarza się, że kawa odbywa się ciągle w domu jednej ze stron spotkania i brakuje wymiany społecznej na zasadzie „ty zapraszasz mnie, to ja ciebie”. W takich przypadkach mogą pojawić się napięcia z powodu 
asymetrii nakładów. Kawa nie wymaga wiele, ale jeżeli stanie się rutynowym, częstym spotkaniem u jednej ze stron, może powstać przekonanie, że to nie jest sprawiedliwe. Gość powinien wtedy sporadycznie przynosić kawę i słodkości ze sobą.

To jest mój gość, dobry gossć, lubię jak ten gość przyjdzie i na przykład coś przyniesie. Lubię. Czy tam dla dziecka cukiereczek, czy tak coś dla mnie, raz kiedyś jakąś kawę, bo ja tak robię. Bo mam taką koleżankę, która do mnie praktycznie w ogóle nie przychodzi, a ja do niej wiecznie na kawę. Dzwonię do niej, „stuchaj, jestem tu koto ciebie, w Biedronce robię zakupy, zaraz wpadnę do ciebie na kawkę”. „Dobra, nie ma sprawy". No i tak zawsze... Albo raz na kwartat ta kawkę kupie, ja się nie czuje winna temu, że ja ja wiecznie opijam. A ona do mnie raczej nie przychodzi. [wywiady-gościnność, K, 40-50, zawodowe, bezrobotna, miasto $>50$ tys.]

\section{„CORAZ MNIEJ” GOŚCINNOŚCI?}

W toku wywiadów dotyczących gościnności pojawiło się pytanie o to, czy Polacy są gościnni. Odpowiadano na nie zwięźle i twierdząco, nie rozwijając tego wątku. Można jednak uznać, że autostereotyp polskiej gościnności ${ }^{11}$ podtrzymuje się jedynie werbalnie, na zasadzie, że tak trzeba i wypada powiedzieć. Potwierdzają to podsumowania własnych doświadczeń rozmówców, którzy zwracali uwagę na tendencję zaniku gościnności, będącą wskaźnikiem zmiany w mentalności społeczeństwa polskiego. Negatywną ocenę zmiany w tym zakresie próbowano określić za pomocą następujących wyrażeń: społeczeństwo „zamyka się”, „ludzie są nieczuli i zawistni”, „coraz rzadziej widzimy się”, „coraz częściej piszemy SMS-y".

Ja teraz nie mogę pojąć, że tu w bloku mieszkam, a ludzie z bloku latami do mnie nie zagladaja. Teraz jakaś taka obojętność, znieczulica. [wywiady-gościnność, K, $<60$, podstawowe, emerytka, miasto $>50$ tys.]

11 Znaczenie autostereotypu polskiej gościnności dla tożsamości Polaków dokumentują badania: „W 2010 roku w badaniach prowadzonych przez Centrum Badania Opinii Publicznej (CBOS) ankietowani proszeni o określenie, z czego Polacy jako ogół społeczeństwa mogą być dumni, w pierwszej kolejności wskazali na gościnność (51\%). W 2015 roku gościnność została wybrana przez $8 \%$ ankietowanych jako najcharakterystyczniejsza polska cecha (po pracowitości - 25\%, malkontenctwie - 17\%, serdeczności - 12\% i zaradności - 10\%). W badaniach „Polacy o sobie”, przeprowadzonych dla „Polityki” przez Kantar Public w lipcu 2017 roku ankieterzy poprosili 1000 dorosłych osób, by wskazały, które cztery cechy (z gotowej listy) najlepiej charakteryzują Polaków. Na pierwszym miejscu znalazła się gościnność, wskazana przez $63 \%$ pytanych. Gościnność jako autostereotyp nie traci zatem na sile" (Skowrońska, Mateja-Jaworska 2019, s. 7). 
Znaczy, kiedyś tego byto więcej, tej gościnności takiej. To teraz troszkę jest mniej. Też może z tych względów, że te miasta dzisiaj są dużo większe. [wywiady-gościnność, $\mathrm{M},<60$, wyższe, ksiądz, miasto $>50$ tys.]

Mi się wydaje, że w Polsce ludzie byli bardziej gościnni kiedyśniż teraz. Trochę zepsuła się gościnność polska. Bo kiedyś byto więcej bezinteresowności, a teraz, tak — wszyscy są bardziej zorganizowani, mają mniej czasu igdzieś gonia. [wywiady-gościnność, $\mathrm{K}, 30-40$, wyższe, nauczycielka, miasto $>50$ tys.]

Na pewno mtodym jest trudniej być gościnnym, bo oni teraz siedza $w$ tym Facebooku, $w$ tych telefonach $i$ komórkach. Wolałabym, żeby starali się więcej spotykać. Córka nawet zauważyła, że więcej teraz piszemy esemesów, niż się spotykamy normalnie. Jednak nie każdy chce się spotkać. [wywiady-gościnność, K, 40-50, średnie, kosmetyczka, miasto $>50$ tys.]

Teraz mi się wydaje, że tak nie ma, nie obchodzi się tak hucznie tych imienin, urodzin jak kiedyś. Jednak to byto, stoty zastawione, alkohol, a teraz chyba to już zanika. [wywiady-gościnność, K, 30-40, wyższe, doradca finansowy, miasto $>50$ tys.]

Zmieniło się. Zmieniło. Myśle, że już tak nie jest. Jeszcze sa tacy, którzy tak robia, natomiast tak ogólnie to się zmienito, że już w ogóle chyba się rzadziej gościmy. Rzadziej nawet wspólnie jemy. Rodziny rzadziej siadaja wspólnie do jedzenia. Każdy sobie coś tam chwyci, zje. [wywiady-gościnność, $\mathrm{M},<60$, wyższe, ksiądz, miasto $>50$ tys.].

Ludzie sa teraz zmienni. Człowiek człowiekowi jak widzi, że ten się lepiej uśmiecha, czy coś to tego zaraz [...]. Taka jest teraz zawiść, nienawišć. [wywiady-gościnność, $\mathrm{M},<60$, zawodowe, listonosz/kurier, miasto $>50$ tys.]

[...] kiedyś jakoś tam ludzie żyli biedniej generalnie i byli bardziej otwarci. [...] no byty większe rodziny, więc taka ta otwartoś́ jeden na drugiego, dzisiaj większa atomizacja tych poszczególnych ludzi, tych poszczególnych rodzin. To widzimy nieraz w blokach, że powiedzmy jakoś tak jest, tylko tak stużbowo się ludzie widza czy spotykają. Ale generalnie to, no myślę, że trochę mniej jest takiego otwarcia się jednych na drugich. [wywiady-gościnność, $\mathrm{M},<60$, wyższe, ksiądz, miasto $>50$ tys.]

Zgodność obrazu kondycji kultury gościnności w gronie przedstawicieli tak zróżnicowanych grup społecznych pozwala przypuszczać, że doświadczanie zaniku gościnności może być powszechne. Jednym ze wskaźników takich zmian jest to, że coraz mniej jest spotkań organizowanych według zasad tradycyjnej gościnności, która polega na wizycie w domu gospodarza, przygotowaniu potraw i spędzeniu dłuższego czasu w szerszym gronie. Tłumaczy się to zabieganiem, dużą liczbą obowiązków, oddalaniem się od siebie oraz ogólnie zanikiem motywacji do częstego spotykania się. 


\section{PODSUMOWANIE}

Analiza wypowiedzi respondentów pozwala stwierdzić, że mamy do czynienia z niespójnością dwóch ogólnych zespołów przekonań - dotyczących autostereotypu polskiej gościnności (pozytywnego) oraz tego, co dzieje się we własnym bliskim otoczeniu (negatywnego). Te dwa poziomy refleksji na temat gościnności możemy skonfrontować z praktykami społecznymi i opisywanymi normami ekonomiki gościnności. Wszystkie te aspekty wskazują, że normatywna regulacja gościnności jest ukierunkowana na umiar ${ }^{12}$. Zasada „lepiej więcej niż mniej” odnosząca się do pożądanego stopnia obfitości potraw w gościnie jest bardziej realistyczną i skromniejszą wersją reguły „zastaw się, a postaw się”. Nastawienie na ograniczenie spożycia alkoholu to odejście od wzoru polskiego biesiadowania, łączonego z piciem „na umór”. $Z$ kolei kawa jako minimalny standard gościnności może sugerować, że mamy do czynienia $z$ ustaleniem progu minimum gościnności na innym poziomie niż ten, który istnieje w pamięci o kulturze czasów PRL-u i lat dziewięćdziesiątych. O ukierunkowaniu normatywnym na umiar świadczą też często używane w trakcie rozmowy o gościnności zwroty, takie jak: „bez spiny”, „na luzie”, „lajtowo”, „bez stresu”. Mogą one wskazywać, że gościnność ma dwuznaczny status. Jest ona czymś ważnym, co powinniśmy kultywować, ale jednocześnie „krępuje”, ogranicza; jest czymś, co wywołuje opór i trzeba się z tym zmagać (Brzozowska-Brywczyńska 2019, s. 131-150).

Jeżeli uznamy, że rzeczywiście jest tak jak twierdzą respondenci, że tradycyjna gościnność zanika, jeżeli zgodzimy się, że zasady ekonomiki gościnności sugerują ukierunkowanie na umiar w przeciwieństwie do nadmiarowości zakorzenionej w polskich autostereotypach powiązanych z gościnnością, to pojawia się pytanie: $\mathrm{w}$ jakim stopniu świadczy to o zmianie dokonującej się w etyce polskiej gościnności, o nastawieniu na bardziej racjonalne i długoterminowe dysponowanie zasobami, dystans wobec ulotności na korzyść dbania o własną stabilność materialną, a w jakim jest to podważanie autostereotypów, które nigdy nie były tak powszechne, jak się nam wydaje, stanowiły spadek po mniejszościowej, dworkowej, szlacheckiej i sarmackiej kulturze? Trudno jednoznacznie odpowiedzieć na to pytanie. Wymagałoby to pogłębionych analiz historycznych i szerzej zakrojonych badań. Najprawdopodobniej jest tak, że obie opcje po części są prawdziwe.

12 Teza ta może być problematyczna w odniesieniu do wesel. Jednak i ta sfera spotkań gościnnych przechodzi transformację (np. coraz częstsza zmiana dominującego alkoholu $z$ wódki na wino, $z$ orkiestry na didżeja, brak oczepin). 
Po pierwsze, zebrane dane sugerują, że Polacy dążą ku skromniejszej gościnności oraz coraz częściej korzystają z alternatyw wobec jej tradycyjnej formy (Modrzyk 2019). Respondenci pytani o gościnność często mówili o sytuacjach, które wychodzą poza sztywny podział ról na gospodarza i gościa. Należą do nich wspólne wyjazdy na wakacje, organizowanie imprez składkowych, grille na łonie natury, umawianie się na obiad lub kawę na mieście. Być może integracja i wspólnotowość nadal są kultywowane, ale proces ten ma inne twarze. Dzisiaj, w zagęszczonej normatywnie, opartej na dużej liczbie zobowiązań codzienności, pełnowymiarowa gościnność jest problematyczna, ponieważ zakłóca pełnienie innych ważnych funkcji i ról. Nieuchronnie przesuwa to ją na drugi plan życia codziennego Polaków. Gościnność nie jest w takim ujęciu w centrum życia społecznego, ale staje się jedną z wielu konkurujących sfer.

Po drugie, trudno mówić o sielankowej wspólnotowości, gdy nawet w obrębie rodzin zaczynamy coraz bardziej się różnić. Zwiększanie się liczby nowych różnicujących społecznie czynników (klasowych, genderowych, światopoglądowych, związanych ze stylem życia itd.) sprawia, że trudno o niezakłócony przebieg sytuacji gościny. Być może rzadsze spotykanie się $\mathrm{w}$ rodzinnym gronie to tyle, na ile pozwala niektórym ich tolerancja różnicy? Gościnność jest sytuacją, która konfrontuje nas bezpośrednio $z$ osobami o innych postawach. W takich warunkach trudno o zadowalające wymiany społeczne, wypracowanie wspólnej definicji sytuacji oraz osiągnięcie podobnego poziomu energii emocjonalnej. W związku z tym gościnność może zacząć kojarzyć się z doświadczeniami, których chcemy uniknąć lub zamierzamy jak najrzadziej doświadczać.

Po trzecie, można przypuszczać, że polska, zastawna, nadmiarowa gościnność, często łączona $z$ tolerancją i otwartością, była mitem (Barthes 2008), który służył jako moralne zrównoważenie kompleksów odnoszących się do sfery sprawnościowo-logistycznej dotyczącej bogactwa państwowego, nowoczesnej infrastruktury, osiągnięć w sferze naukowej, sportowej, artystycznej (Bilewicz 2008, s. 2-36). Przegrywając na tych polach, zawsze można było być moralnym zwycięzcą — między innymi gościnnym Polakiem ${ }^{13}$. Wzrost dostępu do dóbr oraz coraz wyższy poziom konsumpcji powodujący, że odświętność nie kontrastuje jak kiedyś z codziennością niedoborów, sprawia, że nadmiarowa gościnność traci powab i wyjątkowość. Być może krytyczne głosy respondentów dotyczące zaniku gościn-

${ }^{13}$ Inne kategorie powiązane $z$ figurą moralnego zwycięzcy to na przykład bohaterstwo wojenne, mesjanizm, Polska jako przedmurze chrześcijaństwa, przeszła tolerancja Polaków wobec różnic religijnych. 
ności nie uwzględniają tego, że jest to cena za wygraną na innych polach? W takim przypadku zmniejszenie roli gościnności byłoby wskaźnikiem zwiększenia indywidualnej przestrzeni samorealizacji.

\section{BIBLIOGRAFIA}

Barthes Roland, 2008, Mitologie, tłum. Adam Dziadek, Fundacja Aletheia, Warszawa.

Berger Peter L., Luckmann Thomas, 1983, Społeczne tworzenie rzeczywistości, tłum. Józef Niżnik, Państwowy Instytut Wydawniczy, Warszawa.

Bilewicz Michał, 2008, Być gorszymi. O reakcjach na zagrożenie statusu grupy własnej, Wydawnictwa Uniwersytetu Warszawskiego, Warszawa.

Blau Peter M., 2006, Wymiana społeczna, tłum. Dariusz Niklas, w: Aleksandra Jasińska Kania, Lech M. Nijakowski, Jerzy Szacki, Marek Ziółkowski (red.), Wspótczesne teorie socjologiczne, t. 1, Scholar, Warszawa, s. 82-92.

Bourdieu Pierre, 2006 Dystynkcja: klasy i klasyfikacje, tłum. Piotr Biłos, w: Aleksandra Jasińska Kania, Lech M. Nijakowski, Szacki Jerzy, Marek Ziółkowski Marek (red.), Współczesne teorie socjologiczne, t. 2, Scholar, Warszawa, s. 634-650.

Bourdieu Pierre, 2009, Co tworzy klasę społeczną? O teoretycznym i praktycznym istnieniu grup, „Recykling Idei”, nr 11, s. 36-46.

Brzozowska-Brywczyńska Maja, 2019, Akrobatyczny wymiar gościnności albo kilka uwag o tańcu na linie gościa z gospodarzem, w: Bogumiła Mateja-Jaworska, Marta Skowrońska (red.), Gość $w$ dom. Wspótczesne praktyki przyjmowania gości, Wydawnictwo UAM, Poznań, s. 131-150.

Collins Randall, 2011, Łańcuchy rytuatów interakcyjnych, tłum. Katarzyna Suwada, Nomos, Kraków.

Kvale Steinar, 2004, Interviews. Wprowadzenie do jakościowego wywiadu badawczego, tłum. Stanisław Zabielski, Trans Humana, Białystok.

Drozdowski Rafał, 2010, Socjologia codzienności, czyli jak przestać „być modna”?, „Kultura i Społeczeństwo", nr 1, s. 3-15.

Drozdowski Rafał, 2012, Kontraktowanie codzienności, czyli jak można lepiej zintegrować socjologię codzienności z socjologia, w: Tomasz Maślanka, Konstanty Strzyczkowski (red.), Między rutyna a refleksyjnościa. Praktyki kulturowe i strategie życia codziennego, Wydawnictwa Uniwersytetu Warszawskiego, Warszawa.

Elias Norbert, 1980, Przemiany obyczajów w cywilizacji Zachodu, tłum. Tadeusz Zabłudowski, Państwowy Instytut Wydawniczy, Warszawa.

Goffman Erving, 2006a, Pierwotne ramy interpretacji, tłum. Marek Ziółkowski, w: Współczesne teorie socjologiczne, t. 1, Aleksandra Jasińska Kania, Lech M. Nijakowski, Jerzy Szacki, Marek Ziółkowski (red.), Scholar, Warszawa, s. 336-347.

Goffman Erving, 2006b, Rytuat interakcyjny, tłum. Alina Szulżycka, Wydawnictwo Naukowe PWN, Warszawa.

Granovetter Mark S., 1973, The Strength of Weak Ties, „American Journal of Sociology”, t. 78(6), s. 1360-1380.

Krajewski Marek, 2019, Stót, w: Bogumiła Mateja-Jaworska, Marta Skowrońska (red.), Gość w dom. Wspótczesne praktyki przyjmowania gości, Wydawnictwo UAM, Poznań, s. 19-50.

Lorentz Konrad, 1996, Tak zwane zło, tłum. Anna D. Tuszyńska, Państwowy Instytut Wydawniczy, Warszawa. 
Małkowicz-Daszkowska Zofia, 2019, Czynnik dziecięcy —o dziecięcych rolach $i$ statusach $w$ okolicznościach gościny, w: Bogumiła Mateja-Jaworska, Marta Skowrońska (red.), Gość w dom. Wspótczesne praktyki przyjmowania gości, Wydawnictwo UAM, Poznań, s. 175-192.

Mateja-Jaworska Bogumiła, 2019, Gościnne Polaków rozmowy, w: Bogumiła Mateja-Jaworska, Marta Skowrońska (red.), Gość w dom. Wspótczesne praktyki przyjmowania gości, Wydawnictwo UAM, Poznań, s. 51-96.

Modrzyk Ariel, 2019, Utracona gościnność? Reguła tradycyjnej gościnności jako norma średniego zasięgu, w: Bogumiła Mateja-Jaworska, Marta Skowrońska (red.), Gość w dom. Wspótczesne praktyki przyjmowania gości, Wydawnictwo UAM, Poznań, s. 151-173.

Nahirny Rafał, 2015,Polityka stabych więzi, w: Leszek Koczanowicz, Katarzyna Liszka, Rafał Włodarczyk (red.), Między zrozumieniem a porozumieniem. Eseje o demokracji niekonsensualnej, Wydawnictwo Naukowe PWN, Warszawa, s. 111-124.

Skowrońska Marta, 2019, Czuj się jak u siebie, ale bez przesady. Kontrola przestrzeni $i$ opieka nad gościem — dwa wymiary asymetrii władzy w sytuacji gościny, w: Bogumiła Mateja-Jaworska, Marta Skowrońska (red.), Gość w dom. Współczesne praktyki przyjmowania gości, Wydawnictwo UAM, Poznań, s. 97-130.

Veblen Thorstein, 1998, Teoria klasy próżniaczej, tłum. Janina Frentzel-Zagórska, Muza, Warszawa.

\title{
SELF-LIMITING SOCIABLITY: \\ FOOD, ALCOHOL, COFFEE, AND THE THREE PRINCIPLES \\ OF HOSPITALITY ECONOMICS
}

\author{
Ariel Modrzyk \\ (Adam Mickiewicz University in Poznań)
}

\begin{abstract}
The author of the text focuses on the economics of everyday life as defined by a contextual and qualitative measuring of various aspects of hospitality through the use of terms such as "more," "less," and "just right." He analyzes the presence of food, alcohol, and coffee during the visit of guests. Each of these three material components of hospitality is regulated according to specific principles: "too much is better than too little" in regard to food, "too little is better than too much" for alcohol, and there has to be "at least" coffee. A detailed analysis of these principles leads to the conclusion that Polish hospitality is today oriented toward moderation. The popular belief in the abundance of Polish hospitality as a national feature is thus called into question.
\end{abstract}

Key words: hospitality, sociology of everyday life, alcohol, coffee, food

Stowa kluczowe: gościnność, socjologia życia codziennego, alkohol, kawa, żywność 